\title{
Management of superficial basal cell carcinoma: focus on imiquimod
}

This article was published in the following Dove Press journal:

Clinical, Cosmetic and Investigational Dermatology

9 June 2009

Number of times this article has been viewed

\section{Beverly Raasch \\ Skin Cancer Research Group, North Queensland Centre for Cancer Research, James Cook University, Queensland, Australia}

\begin{abstract}
Superficial basal cell carcinoma comprise up to $25 \%$ of all histological sub-types. They are more likely to occur on younger persons and females and although generally more common on the trunk, also occur frequently on the exposed areas of the head and neck especially in areas of high sun exposure. In the last decade, new treatment options such as topical applications that modify the immune response have been trialed for effectiveness in treating these lesions. Imiquimod 5\% cream has been shown to stimulate the innate and cell mediated immune system. The short-term success of imiquimod 5\% cream in randomized controlled trials comparing different treatment regimes and dosing as a treatment for small superficial basal cell carcinoma (BCC) not on the face or neck is in the range of $82 \%$ for 5 times per week application. A high proportion of participants with good response rates to topical treatment (58\%-92\%) experience local side effects such as itching and burning, less commonly erosion and ulceration, but the proportion of participants ceasing treatment has not been high. To date one long-term study indicates a treatment success rate of $78 \%-81 \%$ and that initial response is a predictor of long-term outcome. Recurrences tend to occur within the first year after treatment. Future research will compare this preparation to the gold standard treatment for superficial $\mathrm{BCC}$ - surgical excision.
\end{abstract}

Keywords: superficial basal cell carcinoma, imiquimod, skin cancer

\section{Introduction}

Basal cell carcinoma (BCC) is the most common skin cancer in fair skinned populations and the incidence of BCC continues to rise by approximately $10 \%$ per year. BCC can be classified into different histological sub-types according to their growth pattern. ${ }^{1,2}$ The different histological sub-types broadly distinguish between nodular, superficial and infiltrative and other less frequently occurring types according to their growth patterns. ${ }^{3}$ Micro-nodular and infiltrative sub-types are recognized as high risk and should rarely be treated other than surgically. Apart from the histological appearance, other well- recognized factors that can influence the prognosis and outcomes for treated $\mathrm{BCC}$ are the size and site of the tumor, how clearly the margins are defined and failure of previous treatment. ${ }^{2}$

The aim of this review is to examine the literature to identify the factors that can help a clinician decide whether or not the topical application imiquimod $5 \%$ cream is an appropriate treatment for a patient with the superficial sub-type of BCC (sBCC). The paper will outline the evidence supporting its use and the situations in which it is most likely to be successful, the most appropriate treatment regime and the expected disadvantages and side-effects of this treatment modality for this type of lesion. 


\section{Review criteria}

The information for this review was compiled by searching the PubMed, Cochrane, MD Consult and DARE databases and hard copy and electronic journals of dermatology, cancer and therapeutics. The search terms used included 'reviews' and 'trials', 'randomized controlled trials' 'basal cell carcinoma' 'superficial basal cell carcinoma, 'sBCC' and 'BCC' and 'treatment with imiquimod' 'cost of treatment.' Electronic early-release publications were also included. Only articles published in English were considered. When possible, primary sources have been quoted. Full articles were obtained and references were checked for additional material when appropriate. References were chosen on the basis of the best clinical or laboratory evidence, especially if the work had been corroborated by published work from other centers.

\section{Definition and epidemiology and of sBCC}

The superficial type BCC makes up $25 \%-26 \%$ of all BCCs in sun-exposed Australians with age-standardized incidence rates of 337/100,000/year for males and 251/100,000/year for females compared with $15 \%-16 \%$ of the total types in Europe. ${ }^{4}$ From reports in Europe the superficial type is more likely to occur on the trunk and in the younger age groups especially in females. ${ }^{5}$ In Australia, although still less common than the nodular type, compared with Europe, there are proportionately more $\mathrm{sBCC}$, and in females the incidence is maximum in the 40-49 years age group. The relative tumor density is highest on the face although the highest proportion of $\mathrm{SBCC}$ is on the trunk in males. ${ }^{4}$ Clinically, sBCC are erythematous, slightly scaly, well-defined patches, most commonly found on the trunk and the limbs. However, as mentioned in highly sun-exposed population are also common on the face. ${ }^{4}$ They grow slowly and can be confused with patches of psoriasis or eczema or even fungal infections Although the lesion is more likely to be superficial, they can be large $(>10 \mathrm{~mm})$ identifying the margin when excising the lesions can be quite difficult, and they may be inadequately excised and so recur. ${ }^{6}$ Recurrence of excised BCC can occur up to 10-20 years post treatment and may potentially exceed $50 \%$. However, this does not necessarily apply to sBCC types. ${ }^{7}$ Understanding the etiology and histopathology of these lesions is important because it helps to explain the difficulty in clinical diagnosis and therefore the role of an immune response modifier in treatment.

\section{Etiology}

Evidence suggests that BCC may arise from the pluripotent cells in the basal layer or follicles of the skin. Mutations in the PATCHED (PTCH) gene, a negative regulator of hedgehog signaling, located on chromosome 9 appear to be responsible for the tumor growth in basal cell nevus syndrome (BCNS), an autosomal condition characterized by multiple BCCs. Mutations in the PTCH gene have also been reported in sporadic cases of $\mathrm{BCC}$ and xeroderma pigmentosum associated with BCC. A recent study that focused on cases of sporadic BCC showed that almost half of the tumors examined bore $\mathrm{PTCH}$ gene mutations, and the percentage and type of these mutations did not differ significantly among patient groups that had regular, multiple, or early-onset $\mathrm{BCC} .^{8}$

In general, $\mathrm{BCC}$ are made up of nests of cells representing the basal epidermal layers with peripherally palisading cells. The cells have hyperchromatic nuclei and scant cytoplasm. The nests of tumor cells are surrounded by stroma. Intercellular bridges are not visible on light microscopy. Mitotic figures are common but the whole appearance is one of uniformity rather than anaplasia. Ulceration is not uncommon in large tumors. In long-standing or aggressive lesions, extension is often diffuse or in the paths of cutaneous adnexae. Perineural invasion is seen in about $1 \%$ of cases, more frequently in aggressive forms of BCC. A variable inflammatory infiltrate is often present, usually with a majority of (CD4+) T cells. There is a prominent stroma arranged in bundles around the tumor masses. The (multifocal) superficial type is characterized by numerous small nests of tumor cells usually attached to the undersurface of the epidermis by a broad base. Approximately $10 \%-15 \%$ of all BCCs are of this type. This is the most common pattern seen in BCCs of the shoulder. ${ }^{6,89}$

\section{Treatment options for sBCC}

There are a variety of treatment options for $\mathrm{BCC}$ as a whole, including the superficial sub-type; however, little research has been done comparing the treatment options for this specific sub-type taking into account such factors as age of the patients, body site of the lesions, operator skills, with adequate followup and assessing in addition to recurrence rates, the patient outcomes of cosmesis and quality of life (QOL). ${ }^{10}$

In examining the role of topical applications for the $\mathrm{SBCC}$ it may therefore be necessary to define more clearly where surgery is inappropriate or not first line treatment so that the less invasive options such as topical applications can be recommended.

\section{Surgery and destructive modalities in the treatment of sBCC}

Included in the surgical option for treatment are a number of different modalities including complete primary excision, 
Mohs surgery and the destructive treatments of curettage and cautery, and cryosurgery. ${ }^{1}$ These procedures have pros and cons when it comes to $\mathrm{SBCC}$.

The overall treatment with the best evidence base for primary sBCC and other subtypes is still surgical with recurrence rates of $<2 \%$ and good cosmetic results. This outcome depends significantly on the size of the lesion. For a tumor $\leq 2 \mathrm{~cm}$, the control rate at 5 years expected at 95\% with a tumor $\leq 5 \mathrm{~cm}$ and deeply invading beyond subcutaneous tissues having a control rate from as low as $50 \%$. $^{2,11}$ The reason for a good outcome for surgery is the ability to examine the histopathology of specimens and to determine the adequacy of margins. Successful primary excision reduces the recurrence of any type of BCC including sBCC. ${ }^{11}$ In general, nodular and superficial sub-types, which account for the majority of lesions, do not have aggressive features and have a higher rate of complete excision and lower recurrence rates. ${ }^{12,13}$ Nevertheless, up to $38 \%$ of tumors in one series were mixed sub-types of BCC, and so what appears to be a simple sBCC may behave like the most aggressive sub-component which is unrecognized clinically and may be missed even when biopsied. ${ }^{14}$ GPs in Australia who treat most sBCC in their practices report treating over half $(57 \%)$ with surgery. ${ }^{15}$

Mohs surgery in general would not be undertaken for a sBCC unless a recurrent lesion on a high risk area. It is a highly specialized surgical procedure combining staged procedures with examination of all margins, and aims to remove all tumor, with tissue sparing and reconstruction if necessary. It is a procedure not available in all areas of high skin cancer incidence, ${ }^{14}$ and it is generally reserved for high risk or recurrent lesions and where there is perineural or perivascular involvement. ${ }^{2}$

The strength of the evidence for use of curettage and cautery alone is weak and limited to evidence provided by multiple time series and successful results depend on careful selection of low risk lesions, preferably not on the face where it is less successful and on the skill and experience of the operator. ${ }^{2}$ It has been a preferred method used by dermatologists to treat primary $\mathrm{nBCC}$ and $\mathrm{sBCC}<1.5 \mathrm{~cm}$ although recent data on recurrence rates are limited. ${ }^{16}$ It has been used in conjunction with newer treatments such as topical applications and PDT especially for nodular $\mathrm{BCC}^{17,18}$ and will be discussed further below in association with the use of imiquimod cream.

Cryosurgery is a common form of treatment for BCC in dermatological practice where it is most suitable for primary, well-defined superficial lesions of low risk on other than the head and neck. ${ }^{11}$ Many large older studies demonstrate satisfactory cure rates. One review including studies up to and including 1997, suggested recurrence rates with this modality of from $4 \%$ to $17 \% .{ }^{19}$ A more recent review revealed that there is a dearth of prospective, randomized controlled trials with a 5-year follow-up and that recurrence rates are variable. ${ }^{20}$ Success is technique dependent and one review of multiple series reported a recurrence rate of $7.5 \%$ compared with other treatment modalities. ${ }^{21}$ This technique has been successfully used to treat $\mathrm{sBCC}$ with single freeze thaw cycles achieving cure rates of $96 \%{ }^{22}$ One of the disadvantages of this type of treatment is the perioperative pain, tenderness, blistering and sloughing of necrotic tissue, with possible hypopigmentation and scarring as the outcome and the difficulty associated with identifying recurrence in scar tissue. ${ }^{23}$

In the most recent Cochrane review of interventions for $\mathrm{BCC}^{10}$ only three randomized controlled trials (RCTs) were identified comparing surgical excision with an alternative treatment. First, surgical excision versus radiotherapy $(\mathrm{RT})^{24}$ which does not specifically differentiate between types of BCC although sBCC were included. Second, surgical excision versus Mohs ${ }^{25}$ which looks at high-risk BCCs only, and third, surgical excision versus photodynamic therapy $(\mathrm{PDT})^{26}$ which includes only nodular BCC. Cryosurgery has been compared with radiotherapy and excision ${ }^{27,28}$ and PDT. ${ }^{29,30}$ Although the trial where cryosurgery was compared with PDT identifies sBCC $(n=39)$ in treatment it does not mention how these specifically fared following the intervention compared with other types. The latter trial of 5-year follow-up of treatment of sBCC by cryosurgery (105 lesions on 58 patients) versus PDT looked at ( $\mathrm{n}=114$ lesions) of small size on 60 patients and although the outcome significantly favored PDT for patient tolerability and cosmesis, there was still a high recurrence rate of $20 \%$ for cryosurgery compared with $22 \%$ with PDT. These trials are outlined in Table 1. No randomized controlled trials (RCTS) are reported comparing cautery and curettage with any other treatment modality although curettage was used to debulk tumors in one study. ${ }^{28}$

\section{Photodynamic therapy (PDT)}

This modality uses topical photosensitizing agents aminolevulanic acid (ALA) and MAL, its methylated ester, which are applied topically to the lesion and allowed to stay on the skin and be absorbed for a period of time before being subjected to a specific light source. These agents are relatively selectively concentrated in the lesions and when exposed to the light source, usually in the wavelength of 620 to $670 \mathrm{~nm}^{1}$, this concentration results in photodestruction of the lesion. Other light sources are also used in PDT including lasers, filtered xenon arc and metal halide lamps, fluorescent lamps and light-emitting diodes. Studies have suggested there is a place for the treatment of 
Table I Comparison trials of treatment where sBCC are specifically included

\begin{tabular}{|c|c|c|c|}
\hline Intervention trial & Inclusion & Follow up & Outcome \\
\hline Excision vs $\mathrm{RT}^{24}$ & $\begin{array}{l}\text { Included primary tumors } \\
\mathrm{sBCC}(\mathrm{n}=36) \text { among } \\
\text { other types, face, }<40 \mathrm{~mm}\end{array}$ & $\begin{array}{l}\text { Follow-up } 4 \text { years: } \\
\text { histopathology, primary } \\
\text { and secondary }\end{array}$ & $\begin{array}{l}\text { Primary: recurrence and } \\
\text { secondary cosmesis both } \\
\text { favored surgery }\end{array}$ \\
\hline $\begin{array}{l}\text { Excision vs cryosurgery }{ }^{28} \\
\text { Note: curettage also used to } \\
\text { debulk some tumors }\end{array}$ & $\begin{array}{l}\mathrm{n}=103, \mathrm{sBCC}, \mathrm{nBCC} \text { head } \\
\text { and neck }<2 \mathrm{~cm}\end{array}$ & $\begin{array}{l}\text { Follow-up I year: clinical } \\
\text { superficial (cryosurgery } \\
n=8 \text {, excision } n=6) \\
\text { nodular cryosurgery } n=40 \text {, } \\
\text { excision } n=42\end{array}$ & $\begin{array}{l}\text { Favored surgery for cosmesis, } \\
\text { and no significant difference for } \\
\text { clinical recurrence }\end{array}$ \\
\hline $\begin{array}{l}\text { Surgical excision vs curettage plus } \\
\text { cryosurgery }(C \& C)^{74}\end{array}$ & $\begin{array}{l}\mathrm{n}=100, \mathrm{sBCC} \mathrm{n}=4 \\
\text { (all treated with excision) } \\
\mathrm{nBCC} \mathrm{n}=96\end{array}$ & Follow-up 5 years $n=85$ & $\begin{array}{l}\text { Statistically non-significant } \\
\text { (C\&C19.6\% vs SE 8.4\%) }\end{array}$ \\
\hline Cryosurgery vs $\mathrm{RT}^{75}$ & $\begin{array}{l}\text { ? histological sub-types } \\
\mathrm{n}=93\end{array}$ & $\begin{array}{l}\text { Follow-up I year: } \\
\text { histpathology }\end{array}$ & $\begin{array}{l}\text { Favored RT comparable } \\
\text { cosmetic }\end{array}$ \\
\hline Cryosurgery vs $\mathrm{PDT}^{29}$ & $\mathrm{sBCC} n=39, \operatorname{nod} n=49$ & $\begin{array}{l}\text { Follow-up I year } \\
\text { Histopathology }(n=83)\end{array}$ & $\begin{array}{l}\text { Significantly favored PDT for } \\
\text { patient tolerability and cosmesis. } \\
\text { Recurrence } 25 \% \text { (II of } 44 \text { ) for } \\
\text { ALA-PDT and I5\% (6 of 39) for } \\
\text { cryosurgery. }\end{array}$ \\
\hline Cryosurgery vs $\mathrm{PDT}^{30}$ & $\begin{array}{l}\mathrm{sBCC} n=245, \text { thickness } \\
<\mathrm{I} \mathrm{mm,} \mathrm{diam}<3 \mathrm{~mm}\end{array}$ & Follow-up 5 years $(n=193)$ & $\begin{array}{l}\text { Significantly favored PDT for } \\
\text { patient tolerability and cosmesis, } \\
\text { but no sig diff in recurrence } \\
\text { ( } 20 \% \text { cryo vs } 22 \% \text { PDT) }\end{array}$ \\
\hline Curettage and cautery & none & & \\
\hline
\end{tabular}

Abbreviations: ALA, aminolevulanic acid; RT, radiotherapy; PDT, photodynamic therapy; C\&C, curettage and cryosurgery; SE, surgical excision; sBCC, superficial basal cell carcinoma.

sBCC with PDT, ${ }^{2}$ although they may not clear with a single treatment and that results are better with two cycles. ${ }^{31}$ One $\mathrm{RCT}^{18}$ examined $\mathrm{sBCC}(\mathrm{n}=245$ lesions on 83 patients $)$ using topical ALA and 2 different light sources and there was no significant difference in the clinical or cosmetic outcomes at 6 months. As mentioned above, PDT has been compared with cryosurgery in an RCT, but not specifically for sBCC and not against other noninvasive modalities such as topical 5-fluorouracil (5FU) which has Federal Drug Authority approval for treatment of sBCC where conventional methods are impractical, or the immune-response modifier imiquimod.

\section{Topical applications}

A body of literature and trials are now available looking at topical applications in the treatment of sBCC, although it is not always easy to determine whether the sub-type of BCC has been clearly defined. ${ }^{4,2}$ In addition, a successful outcome for treatment needs to be explicit and it is recommended that 5- to 10-year local control rates or recurrence rates are legitimate measures although most studies do not go beyond 5 years. ${ }^{11}$ As with any treatment modality the desired primary outcome is to totally eradicate the tumor and secondly to do so with as good a cosmetic outcome and patient acceptance as possible yet comparative data for different treatments is sparse, with most topical application studies now either comparing different treatment regimes or long-term follow-up rather than against other intervention types. ${ }^{2}$

For example, the actual clearance rate for treatment for sBCC with 5FU is currently not known because of a lack of adequate trials. The only open-label randomized trial available includes superficial and nodular BCC and compared six different treatment regimes. Overall there was an $8 \%$ treatment failure for sBCC when followed up by histological examination at 3 months. ${ }^{32}$ One 1-year follow-up study comparing $5 \mathrm{FU}$ with imiquimod for actinic keratoses $(\mathrm{AK})$ is reported. ${ }^{33}$

\section{Focus on imiquimod for sBCC Mode of action}

Imiquimod is a synthetic preparation that acts as an immune response modifier and its clinical effect comes from cytokine activation of the immune system and possibly also from induced apoptosis in BCC cells. ${ }^{34}$ It has been used now for some years in the treatment of genital warts as a topical application where it stimulates the production of cytokines including interferon alpha through activation of Toll-like receptors (TLR) - 7 on antigen presenting cells. ${ }^{35}$ It promotes 
the innate immune response and the cell-mediated immune pathway. This immune modification has also been shown to produce anti-proliferative and anti-tumor activity. ${ }^{36,37}$

In examining biopsies of sBCC before and after treatment and undertaking gene studies and immunohistochemistry, it has been found that imiquimod has an anti-tumor effect on sBCC. This effect is mediated by the stimulation of the dendritic cells in the epidermis and dermis to release interferon (IFN) $\alpha$ and other cytokines, thus activating the innate immune system with activity against tumor cells resulting in apoptosis. ${ }^{38,39}$ A recent double blind placebo-controlled randomized parallel group trial designed to identify the early immunological events caused by the application of imiquimod when used to treat BCC (type not indicated) found that the early mode of action was characterized by the stimulation of a large number of genes (637) which were highly specific to imiquimod action, 98 of which confirmed previous involvement of interferon $\alpha$ (IFN- $\alpha)$. With the remaining genes IFN $\gamma$ transcription was more prevalent than the former. The most striking effects after several days of application were on cytoxic mechanisms with significant increases and induction of recruitment and activation of $\mathrm{T}$ and natural killer (NK) cells within the BCC. It was hypothesized that that it is these secondary immune effect mechanisms that induce destruction of target cells. It appears therefore that imiquimod links multiple immune pathways and of these IFN- $\alpha$ plays a consistent but not exclusive role. ${ }^{40}$

A further possible action of imiquimod was demonstrated when it was applied in vitro to squamous cell carcinomas (SCC). It appeared to neutralize the failure of the tumors to express vascular E-selectin. Through this it was able to allow the skin-homing T cells access to the tumor to promote its destruction. In addition, it reduced the number of tumor infiltrating $\mathrm{T}$ regulatory cells thus tipping the balance of $\mathrm{T}$ cells within the tumor towards CD8+ T cells. Furthermore, it induced interleukin 6 (IL-6) production from the effector $\mathrm{T}$ cells. These actions may also be relevant to $\mathrm{SBCC} .{ }^{41}$

It appears to have minimal impact on normal skin, does not increase ultraviolet (UV) induced change to epidermal keratinocytes or DNA and the systemic absorption is minimal, with $<0.9 \%$ of the dose excreted in urine and $<0.2 \%$ excreted in feces, although flu-like symptoms and headache can occur while using the cream especially in older patients. ${ }^{42,43}$

The effect of imiquimod has also been studied by a new technique of confocal microscopy. This is a noninvasive optical technique that can be used to evaluate skin diseases without biopsy. Unfortunately it is very expensive equipment that would not be available in all centers.
Nevertheless in a small case control study and in one case report the investigators were able to demonstrate the local immune response following therapy with imiquimod and demonstrated how the previously diseased skin improved over time. Histology of the tissue was also carried out to confirm findings. ${ }^{44,45}$

\section{Uses}

In 2004, imiquimod (Aldara ${ }^{\circledR}$; 3M, St. Paul, MN) was approved by the United States Food and Drug Administration (FDA) for the topical treatment of $\mathrm{SBCC}$, based on two doubleblind, vehicle-controlled clinical studies. ${ }^{46,47}$ The indications for use were for the topical treatment of biopsy-confirmed, primary superficial BCC in immunocompetent adults, with a maximum tumor diameter of $2.0 \mathrm{~cm}$, located on the trunk (excluding anogenital skin), neck, or extremities (excluding hands and feet), only when surgical methods are medically less appropriate and patient follow-up can be reasonably assured. ${ }^{48}$

In Australia, following results of the above Phase III trials where clearance rates were $82 \%$, imiquimod cream $5 \%$ is approved for use by the Therapeutic Goods Administration for biopsy-proven primary $\mathrm{sBCC}$, and solar keratoses. Dosing for the former is application to the lesion and $5 \mathrm{~mm}$ surrounding skin 5 times per week for 6 weeks. Treatment breaks are allowed for severe inflammatory reactions. ${ }^{11,47}$ For subsidized use under the Pharmaceutical Benefits Scheme it is approved for the "Treatment of superficial basal cell carcinoma (BCC) in immunocompetent patients who cannot have surgical excision, cryotherapy, or curettage with diathermy. The lesion must be previously untreated and the diagnosis confirmed by biopsy, and the patient or carer must be able to follow the dosing regimen." 49

Approval for use in the UK is for treatment of superficial BCCs that measure up to $2 \mathrm{~cm}$ across (diameter) on the trunk, neck, arms and legs (including hands and feet). ${ }^{50}$

\section{Trials: what do they tell us?}

Initial trials of imiquimod $5 \%$ cream for the treatment of skin cancer focused on s BCC, and were drug-company sponsored studies in prospective open-label dose-response studies in multiple centers in Australia, Europe and the United States. The inclusion criteria for these studies were primary histologically confirmed sBCC lesions, not previously treated, of $<2 \mathrm{~cm}$ diameter or $0.5 \mathrm{~mm}^{2}$ and in a position where it could be later excised. The patients were to have no skin conditions, and be immunocompetent. These first trials indicated that imiquimod could be an effective 
treatment for $\mathrm{sBCC}$ and that an appropriate treatment regime would be a maximum of a daily application, higher dosing causing more and intolerable side effects. The length of treatment was also tested in these studies with tumor treatment of varying times from 6 to 12 weeks, as was the ability to determine clinically whether the tumor had been cleared..$^{51,52}$ The predictive value of clinical diagnosis of tumor non-clearance was $39 \%$ by the investigators, but when clinical diagnosis of positive clearance was compared with histology results investigators were correct in 100\% of cases. ${ }^{46}$ The results of these trials suggested that a clearance rate, based on clinical and histological examination, could be in the range of $73 \%$ to $88 \%$ with a maximum clearance rate with daily applications for 6 weeks.

Of the nine RCTs reported on imiquimod use in the treatment of basal cell carcinoma in the most recent Cochrane review, ${ }^{10}$ only four relate to $\mathrm{sBCC}$, with 128 patients, 724 patients 166 patients and 35 patients respectively ${ }^{35,46,47,51}$ with another relating to $\mathrm{sBCC}$ that was a randomized open label study with 93 patients with sBCC. ${ }^{54}$ These studies are outlined in Table 2. A 3-year primary outcome with 5-year follow-up RCT comparing the use of imiquimod with excisional surgery for the treatment of nodular and sBCC is underway in the United Kingdom. ${ }^{54}$ All the studies have compared the treatment intervention with vehicle and with different doses and dosing regimes. In the most recent Cochrane review all except the study undertaken by Sterry et al were determined to be of medium quality.

In summary, for the larger trials identified, the clearance rates outlined in Table 2 for once-daily 5 to 7 times per week dosing, ranged from overall (clinical and histological combined) $73 \%$ to $75 \%,{ }^{47} 77 \%{ }^{35}$ to $81 \%$ to $87 \%$. ${ }^{46}$ These were higher where the study included twice daily dosing, and lower with lower frequency of dosing. It is interesting to note that the histological clearance rate was higher than the clinically observed clearance rate ${ }^{35,47}$ as reported above. In a pooled analysis of 5 studies testing higher and lower dosing regimes for $\mathrm{BCC}$ (not only $\mathrm{BCC}$ ) there was a $50 \%$ reduction in the risk of early treatment failure with the more frequent dosing regime than the less frequent. ${ }^{10}$

\section{Side effects and disadvantages of treatment}

The side effects from use of imiquimod are mainly local site reactions. In the RCTs, these tended to be complaints of erosion, ulceration and induration (in the more frequent dosing regimes) to itching, burning or pain affecting from $58 \%$ to $92 \%$ of trial participants..$^{35,46,47,51}$ Prescribed or patient-initiated treatment breaks due to side effects ranged from $3 \%$ to $19 \%$. An association was shown between severity of local site reaction and clinical response rate. The more reaction, the better the response. ${ }^{55,56}$ Despite this, few patients in any of the studies discontinued because of the inflammatory response. ${ }^{35,46,47,55,56}$

A recent study reported a case series of 24 patients (6 of whom had sBCC) examining the treatment failures and clinical characteristics associated with failure. The authors in this study emphasize the need to inform patients as to whether their prescribed use of imiquimod meets the approved uses from the drug-regulatory authority and warn of risks associated with transferring responsibility of care for a cancer to the patient rather than the physician. They advise long-term follow-up. ${ }^{57} \mathrm{~A}$ further study reports on persisting hypopigmentation following treatment. ${ }^{58}$

\section{Cost effectiveness of treatment options}

There have been few economic evaluations of the costeffectiveness of various treatment options for non-melanoma skin cancer - even less specifically for sBCC. ${ }^{11}$ In one study in Spain the cost effectiveness of treatment with imiquimod was compared with regular excisional surgery. The findings may not be generalizable because they are based on the Spanish health care system but the principles underlying the assumptions about care such as when, where and by whom treatment is delivered provide a framework that could apply to other geographical regions. The findings indicated reduced costs per patient cured for imiquimod compared to surgical treatment in either a dermatological or non-dermatological service. Costs of primary care physicians were only involved in follow-up and any subsequent late treatment failure costs were not included. ${ }^{59}$ On the other hand, in Australia, General Practitioners (primary care physicians) tend to treat most sBCC, and with surgery, ${ }^{15}$ although there has been no economic evaluation of this care specifically for sBCC in Australia.

\section{Other regimes and options for the use of imiquimod}

More recent trials have focused on the different regimes but with only small numbers of patients, but longer follow-up. Five weeks of $5 \%$ imiquimod cream once daily with a 1 -week interval was more effective but as well tolerated as the 8 -week alternate week regimen for sBCC. ${ }^{60}$ Using occlusion 3 days per week appeared not to improve the success rate for sBCC $(87 \%)$ over the more conventional treatment regime of 


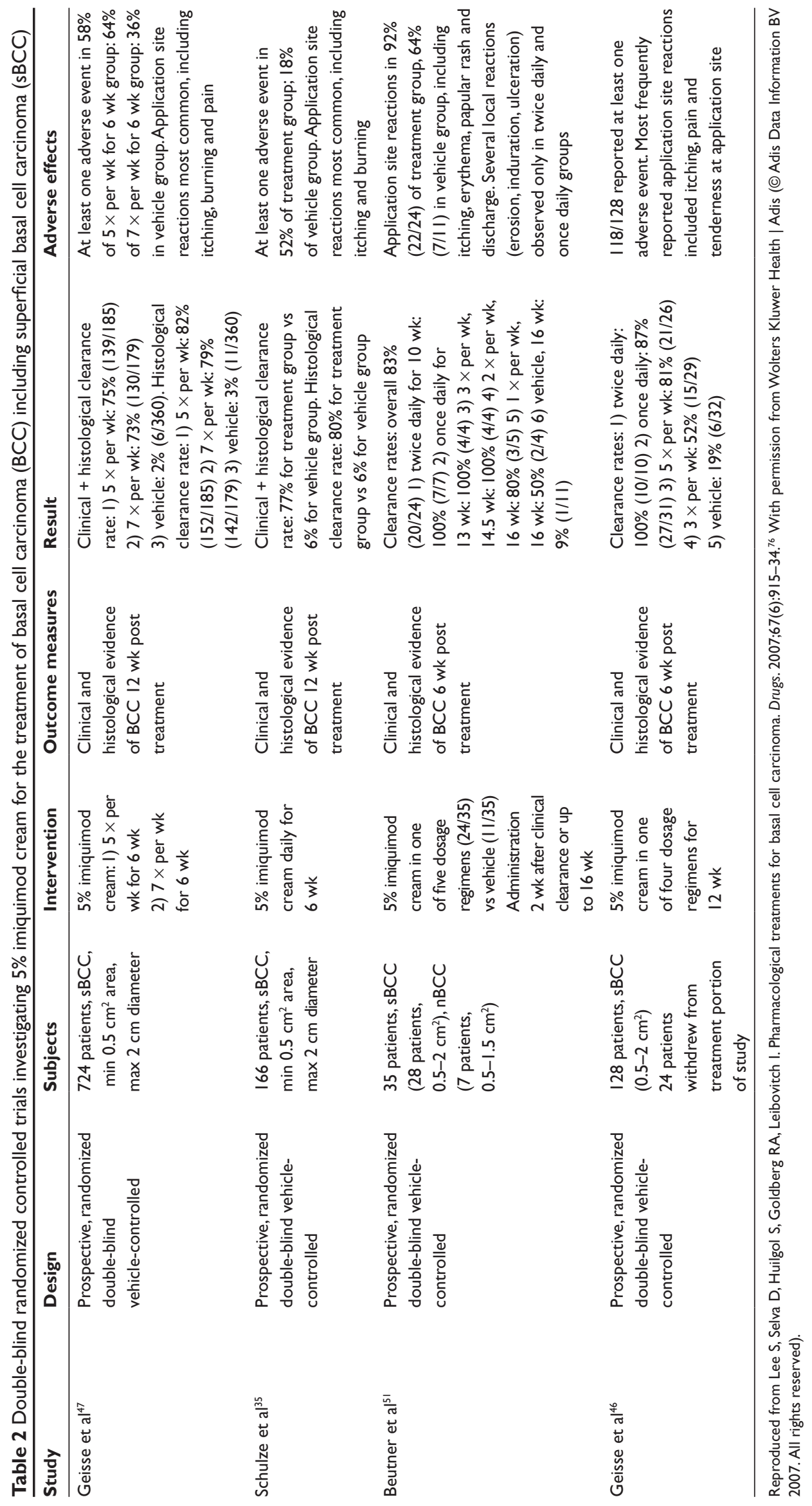


5 times per week for 12 weeks. ${ }^{53}$ One study reports treatment of 96 patients with 141 lesions, 45 of which were biopsy proven sBCC mainly on the face neck or scalp. The patient group was considered to be unsuitable for or had refused surgery. They used the cream 3 days per week with multiple applications from one sachet to reduce cost. This pragmatic carefully designed study produced clinical cure rates of $83 \%$ to $87 \%$ at 6 months and $80 \%$ to $85 \%$ at 1 year despite a less frequent dosing regime. ${ }^{61}$

There is also a scientific rationale for combining surgical techniques with the use of imiquimod either to decrease the initial tumor size or to debulk it or to "mop-up" residual tumor cells following surgery on difficult body sites. ${ }^{62}$ One study reports improved results from this approach. The numbers were small (57)and included sBCC and nBCC where curettage without cautery was performed and followed one week later by imiquimod 5\% cream applied 5 times per week for 6 weeks. At 1-year follow-up there were no clinical recurrences and cosmetic results were reported as excellent. ${ }^{63}$ A further prospective follow-up study also reports treating patients with biopsy confirmed BCC (unknown whether they were superficial type) using currettage followed by imiquimod. A sample of lesions were biopsied at 6 weeks after therapy, two of which showed BCC, but on average follow-up at 36 months of 101 lesions the clearance rates were $96 \%$ with favorable cosmetic outcome. ${ }^{64}$ Imiquimod has also been used as adjunctive therapy where Mohs surgery is planned for $\mathrm{sBCC}$ or $\mathrm{nBCC}$. A report of where Mohs was undertaken for three cases of large mixed-type $\mathrm{BCC}$ was ceased after the removal of aggressive tumor components and the remaining $\mathrm{sBCC}$ received adjuvant therapy with imiquimod cream for 6 weeks showed no recurrences after a follow-up period of 20 to 34 months. ${ }^{65}$

\section{Recurrence and long-term follow-up}

At this stage, in two open label phase III studies of sBCC treatment regimes of once daily 5 or 7 times per week $(n=169)$ application of imiquimod 5\% cream, the 2-year follow-up has been reported. The outcome measure has been a clinical evaluation rather than excision, for obvious reasons. This approach also mimics the reality of clinical practice. The treatment regime in the first study was 5 times per week application for 6 weeks $(n=182)$ of whom 178 completed treatment. The follow-up of this study ${ }^{66}$ has subsequently been published and indicates the overall efficacy of the treatment at 5 years (with all patients included) was $78 \%$ clinically cleared and $81 \%$ histological clearance. One patient who was clear at the 12 -week visit died prior to entering follow-up. It was noted that if recurrences occurred in this study they mostly occurred during the first 9 months after the end of treatment. The initial response was therefore predictive of long-term outcome so these authors recommend and encourage continued monitoring of skin lesions. The second study demonstrated a clearance rate of $94 \%$ at 12 weeks post treatment and those clinically clear at 2 years were $82 \%$ with no difference between five times per week treatment and seven times per week treatment for recurrence, but the more frequent dosing increased side effects. ${ }^{56} \mathrm{~A}$ further small open study of 5-year follow-up for 55 lesions, showed of the four sBCC the long-term clearance rate was $100 \% .{ }^{67}$

\section{Other reports on imiquimod in special case $\mathbf{S B C C}$}

The approval by licensing authorities has focused on the use of this preparation for skin malignancies on small non-head and neck SBCC and AK. Trials are still underway for its use in nBCC, Bowen's disease, and larger lesions, these topics are outside this review. One case report discusses success using imiquimod for a patient with multiple sBCC, after failure of treatment with $5 \mathrm{FU}^{68}$ and a second reports on the effectiveness of imiquimod for a single large $\left(30 \mathrm{~cm}^{2}\right) \mathrm{sBCC}$ with histological assessment at 10 months post treatment. ${ }^{69}$ There are also a number of reports of case series where patients with BCNS (Gorlins syndrome) with multiple facial and trunk superficial and nodular BCC have been treated with a high level of success using imiquimod cream..$^{70,71}$ There may also be a role for the treatment of $\mathrm{sBCC}$ occurring in high risk renal transplant patients with one study reporting that it appears to be safe on skin areas up to $60 \mathrm{~cm}^{2} .^{72}$

\section{Conclusion}

Long-term follow-up of blinded RCTs comparing imiquimod with other interventions are not yet available although these are ongoing. Only one RCT report including SBCC is available for 5-year follow-up and this compares cryosurgery with PDT. While awaiting final outcomes of these studies it would appear that imiquimod should not be first-line treatment for superficial BCC, as surgical excision is more effective. However, the self-treatment regimes and demonstrated efficacy so far are attractive. ${ }^{73}$ There is reasonable evidence that the use of imiquimod for small $(<2 \mathrm{~cm})$ superficial BCC that occur other than on the face provides outcomes only marginally less satisfactory than surgery. There would be a place for imiquimod in treating patients with frequent multiple primary lesions when access to surgery is difficult or where clinical judgment may be influenced by 
patient factors as reported in some of the studies, eg, where patients may have contraindications to surgery. Cosmetic outcome may also be relevant since sBCC occurs more frequently in younger patients.

Monitoring and follow-up are important if using imiquimod. There are a substantial proportion of lesions that do not respond, and this may be because they are unrecognized as having mixed components even if biopsy is performed and patients who have one BCC are at risk of more.

Side effects that are unpleasant and unsightly such as erosion, ulceration, burning and stinging, although commonly occurring in the majority of successful treatments of sBCC, are a two-edged sword. They generally indicate a high level of immune response and are correlated with clearance of the lesion. When patients were warned to expect these side effects, as in the trials, there was a minimal drop out because of them.

\section{Areas for further research}

More research is needed focusing on the use of imiquimod for sBCC on the face, those of larger size, the relationship between cure rates and side effects, and in the role of imiquimod as adjuvant therapy to or prior to surgical procedures especially in cosmetically sensitive areas. In addition, since imiquimod is a self-treatment regime, the outcomes of treatment in patients in rural areas with poor access to specialized care compared with other approaches would be valuable.

\section{Disclosures}

The author has acted as a consultant for 3M Pharmaceuticals.

\section{References}

1. Wong CSM, Strange RC, Lear JT. Basal cell carcinoma. BMJ. 2003;327:794.

2. Telfer NR, Colver GB, Morton CA. Guidelines for the management of basal cell carcinoma. Br J Dermatol. 2008;159:35-48.

3. Heenan PJ, Elder DJ, Sobin LH. Histological typing of skin tumours. 26 In: WHO International Histological Classification of skin tumours, 2nd edn. Berlin: Springer Verlag. 1996;48-51.

4. Raasch BA, Buettner PG, Garbe C. Basal cell carcinoma: histological classification and body-site distribution. Br J Dermatol. 2006 155:401-407.

5. Bastiens MT, Hoefnagel JJ, Bruin JA, et al. Differences in age, site distribution and sex between nodular and superficial basal cell carcinomas indicate different types of tumours. Jnl Invest Dermatol. 1998;110:880-884.

6. DeLauney W, Land W, Rotstein H. Principles and Practice of Dermatology 3rd Edition. Sydney Butterworth Heinemann. 1993.

7. Griffiths RW. Audit of histologically incompletely excised basal cell carcinomas: recommendations for management by re-excision. $\mathrm{Br} J$ Plast Surg. 1999;52:24-28.

8. Roewert-Huber J, Lange-Asschenfeldt B, Stockfleth E, et al. Epidemiology and aetiology of basal cell carcinoma. $\mathrm{Br} J$ Dermatol. 2007;157(Suppl 2):47-51.
9. Jiang SB, Szyfelbein K. Pathology: Basal Cell Carcinoma. In Emedicine, Nawaz S, Talavera F, Sherif M, Slack CL, Meyers AD Editors. Accessed 24 November 2008. http://www.emedicine.com/ent/ TOPIC672.HTM.

10. Bath-Hextall FJ, Perkins W, Bong J, Williams HC. Intervntions for basal cell carcinoma of the skin. Cochrane database Syst Rev: CD003412. Review. 2007

11. Cancer Council Australia and Australian Cancer Network, Basal cell carcinoma, squamous cell carcinoma (and related lesions)-guide to clinical management in Australia. Sydney. 2008.

12. Sexton M, Jones DB, Maloney ME. Histologic pattern analysis of basal cell carcinoma. Study of a series of 1039 consecutive neoplasms. J Am Acad Dermatol. 1990;23(6 Pt 1):1118-1126.

13. Nagore Em Grau C, Molinero J, Fortea JM. Positive margins in basal cell carcinoma:relationship to clilnical features and recurrence risk. A retrospective study of 248 patients. J Eur Acad Dermatol Venereol. 2003;17(2):167-170.

14. Walker P, Hill D. Surgical treatment of basal cell carcinomas using standard postoperative histological assessment. Australas J Dermatol. 2006;47:1-12.

15. Raasch B, Woolley T. Management of primary superficial basal cell carcinoma. Aust Fam Physician. 2006;36(6):455-458.

16. Cielley RI, Del Rosso JQ. Current modalities and new advances in the treatment of basal cell carcinomas. Int J Dermato. 2006;45: 489-498.

17. Wu JK, Oh C, Strutton G, Siller G. An open label pilot study examining the efficacy of curettage followed by imiquimod $5 \%$ cream for the treatment of primary nodular BCC. Australas $J$ Dermatol. 2006;47:46-48.

18. Soler AM, Warloe T, Berner A, Giercksky KE. A follow up study of recurrence andn cosmesis in completely responding superficial and nodular basal cell carcinomas treated with methyl 5-amino laevulinatebased photodynamic therapy alone and with prior curettage. $\mathrm{Br} \mathrm{J}$ Dermatol. 2001;145:467-471.

19. Thissen MT, Neumann MH, Schouten LJ. A systematice review of treatment modalities for primary basal cell carcinomas. Arch Dermatol. 1999;135(10):1177-1183.

20. Kokoszka A Scheinfield N. Evidence - based review of the use of cryosurgery in treatment of basal cell carcinoma. Dermatol Surg. 2003;29:566-571.

21. Rowe DE, Carroll RJ, Day CL Jr. Long-term recurrence rates in previously untreated (primary) basal cell carcinoma: implications for patient follow-up. J Dermatol Surg Oncol. 1989;15(3):315-328.

22. Graham G. Cryosurgery. Clin Plast Surg. 1993;20:131-147.

23. Neville JA, Welch E, Leffell DJ. Management of nonmelanoma skin cancer in 2007. Nat Clin Prac Oncolo. 2007;4:462-469.

24. Avril MF, Auperin A, Margulis A, et al. Basal cell carcinoma of the face: surgery or radiotherapy? Results of a randomized study. $\mathrm{Br} J$ Cancer. 1997;76:100-106.

25. Smeets NW, Krekels GA, Ostertag JU, Essers BA, Dirksen CD, et al. Surgical excision vs Mohs micrographic surgery for basal cell carcinoma of the face: randomized controlled trial. Lancet. 2004;364(9447):1766-1772.

26. Rhodes LE, de Rie M, Enström Y, et al. Photodynamic therapy using topical methyl aminolevulinate vs surgery for nodular basal cell carcinoma:results of a multicenter randomized prospective trial. Arch Dermatol. 2004;140(1):17-23.

27. Hall VL, Leppard BJ, McGill J, Kesseler ME, White JE, Goodwin P. Treatment of basal-cell carcinoma:comparison of radiotherapy and cryotherapy. Clin Radiol. 1986;37:33-34.

28. Thissen MR, Nieman FH, Ideler AH, Berretty PJ, Neumann HA Cosmetic results of cryosurgery versus surgical excision for primary uncomplicated basal cell carcinomas of the head and neck. Dermatol Surg. 2000;26(8):759-764.

29. Wang I, Bendsoe N, Klinteberg CA, et al. Photodynamic therapy vs cryosurgery of basal cell carcinomas:results of a phase III clinical trial. Br J Dermatol. 2001;144(4):832-840. 
30. Basset-Seguin N, Ibbotson SH, Emtestam L, et al. Topical methyl aminolaevulinate photodynamic therapy versus cryotherapy for superficial basal cell carcinoma: a 5 year randomized trial. Eur $J$ Dermatol. 2008;18(5):547-53. Epub 2008 Aug 8.

31. Haller JC, Cairnduff F, Slack G, et al. Routine double treatments of superficial basal cell carcinoma using aminolaevulinic acid-base photodynamic therapy. Br J Dermatol. 2000;143:1270-1275.

32. Miller BH, Shavin JS, Cognetta A, et al. Nonsurgical treatment of basal cell carcinomas with intralesional 5-fluorouracil or epinephrine injectable gel J Am Acad Dermatol. 1997;36(1):72-77.

33. Krawtchenko N, Roewert-Huber J, Ulrich M, Mann I, Sterry W, Stockfleth E. A randomised study of topical 5\% imiquimod vs topical 5 -fluorouracil vs cryosurgery in immunocompetent patients with actinic keratoses: a comparison of clinical and histological outcomes including 1-year follow-up. Br J Dermatol. 2007;157 Suppl 2:34-40.

34. Berman B, Sullivan T, De Araujo T, et al. Expression of FAS receptor on basal cell carcinomas after treatment with imiquimod $5 \%$ cream or vehicle Br J Dermatol. 2003;149(Suppl 66):59-61.

35. Schulze HJ, Cribier B, Requena L, et al. Imiquimod $5 \%$ cream for the treatment of superficial basal cell carcinoma: results from a randomized vehicle-controlled phase III study in Europe. Br J Dermatol. 2005;152:939-947.

36. Tyring S, Conant M, Marini M, van der Meijden W, Was K. Imiquimod; an international update on therapeutic uses in dermatology. Int $J$ Dermatol. 2002;41:810-816.

37. Stanley MA. Imiquimod and the imidazoquinolones: mechanism of action and therapeutic potential. Clin Exp Dermatol. 2002;27:571-577.

38. Dummer R, Urosevic M, Kempf W, Hoek K, Hafner J, Burg G. Imiquimod in basal cell carcinoma: how does it work? $\mathrm{Br} J$ Dermatol. 2003;149(Suppl 66):57-58.

39. Schon MP, Schon M. Imiquimod: mode of action. Br J Dermatol. 2007;157:s2;8-13.

40. Panelli MC, Stashower ME, Slade H, et al. Genome Biology. 2007;8:R8.

41. Clark RA, Huang S, Murphy GF, et al. Human squamous cell carcinomas evade the immune response by down-regulaion of vascular E-selectin and recruitment of regulatory T cells. $J$ Exp Med. 2008;205(10):2221-2234.

42. Hanger C, Dalrymple J, Hepburn D. Systemic side effects from topical imiquimod. N Z Med J. 2005;118(1223):U1682.

43. Wagstaff AJ, Perry CM. Topical Imiquimod: a review of its use in the management of anogenital warts, actinic keratoses, basal cell carcinoma and other skin lesions. Drugs. 2007;67(15):2187-2210.

44. Goldgeier M, Foz CA, Zavislan JM, Harris D, Gonzalez S. Noninvasive imaging, treatment and microscopic confirmation of clearance of basal cell carcinoma. Dermatol Surg. 2003;29(3):205-210.

45. Astner S, Dietterle S, Otberg N, Roewert-Huber HJ, Stockfleth E, Lademann J. Clinical applicability of in vivo fluorescence confocal microscopy for noninvasive diagnosis and therapeutic monitoring of nonmelanoma skin cancer. J Biomed Opt. 2008;13(1):014003.

46. Geisse JK, Rich P, Pandaya A, et al. Imiquimod 5\% cream for the treatment of superficial basal cell carcinoma: a double-blind, randomized vehicle-controlled study. J Am Acad Dermatol. 2002;47:390-398.

47. Geisse J, Caro I, Lindholm J, Golitz L, Stampone P, Owens M. Imiquimod 5\% cream for the treatment of superficial basal cell carcinoma: results from two phase III randomized vehicle controlled studies. J Am Acad Dermatol. 2004;50(5):722-733.

48. Physician's Desk reference. 2006;1815.

49. Australian Government Department of Health and Ageing. July 2006 PBAC outcomes: positive recommendations. Accessed 22 August 2006. http://www.health.gov.au/internet/wcms/publishing.nsf/Content/ pbacrec-pbacrecjul06-positive imiquimod. 2006.

50. Cancer Research UK. http://www.cancerhelp.org.uk/help/default. asp?page $=11892$ Last accessed 25 November 2008 Last updated 11 November 2008.

51. Beutner KR, Geisse JK, Helman D, Fox TL, Ginkel A, Owens ML. Therapeutic response of basal cell carcinoma to the immune response modifier imiquimod 5\% cream. J Am Acad Dermatol. 1999;41(6):1002-1007.
52. Marks R, Gebauer K, Schumack S, et al; Australasian Multicentre Trial Group. Imiquimod $5 \%$ cream in the treatment of superficial basal cell carcinoma; results of a multicenter 6 week dose-response trial. $J \mathrm{Am}$ Acad Dermatol. 2001;44:807-813.

53. Sterry W, Ruzicka T, Herrara E, et al. Imiquimod $5 \%$ cream for the treatment of superficial and nodular basal cell carcinoma: randomized studies comparing low-frequency dosing with and without occlusion. Br J Dermatol. 2002;147:1227-1236.

54. SINS study http://www.nottingham.ac.uk/dermatology/sins.htm. Last accessed 25 November. 2008.

55. Gollnick H, Barona CG, Frank RGJ, et al. Recurrence rate of superficial basal cell carcinoma following successful treatment with iquimod $5 \%$ cream: interim 2 year results from an ongoing 5 year follow-up study in Europe. Eur J Dermatol. 2005;15(5):374-381.

56. Quirk C, Gebauer K, Owens M, Stampone P. Two year interim results from a 5 year study evaluationg clinical recurrence of superficial basal cell carcinoma after treatment with imiquimod $5 \%$ cream daily for 6 weeks. Australas J Dermatol. 2006;47:258-265.

57. Murphy ME, Brodland DG, Zitelli JA. Definitive surgical treatment of 24 skin cancers not cured by prior imiquimod therapy. Dermatol Surg. 2008;34:1-6.

58. Mendonça CO, Yates VM. Permanent facial hypopigmentation following treatment with imiquimod cream. Clin Exp Dermatol. 2006;31(5):721-722.

59. Vanaclocha F, Daudén E, Badía X, et al. Cost effectiveness of treatment of superficial basal cell carcinoma: surgical excision vs imiquimod 5\% cream. Br J Dermatol. 2007;156(4):769-771.

60. Ezughah FI, Dawe RS, Ibbotson SH, Fleming CJ. A randomized parallel study to assess the safety and efficacy of two different dosing regimens of $5 \%$ imiquimod in the treatment of superficial basal cell carcinoma. J Dermatol Treat. 2008;19:111-117.

61. Bukhardt Pérez MP, Ruiz-Villaverde R, Naranjo Díaz MJ, Blasco Melguizo J, Naranjo Sintes R. Basal cell carcinoma: treatment with imiquimod. Int J Dermatol. 2007;46:539-542.

62. Berman B. Scientific rationale: combining imiquimod and surgical treatments for basal cell carcinoma. J Drugs Dermatol. 2008;7(1 Suppl 1): s3-s6.

63. Rigel DS, Torres AM, Ely H. Imiquimod 5\% cream following curettage without electrodessication for basal cell carcinoma: preliminary report. J Drugs Dermatol. 2008;7(1 Suppl 1):s15-s16.

64. Tillman DK Jr, Carroll MT. A 36 month clinical experience of the effectiveness of curettage and imiquimod $5 \%$ cream in the treatment of basal cell carcinoma. J Drug Dermatol. 2008;7(1Suppl1): s7-s14.

65. Thissen MR, Kuijpers D, Krekels GA. Local immune modulator (imiqumod 5\% cream) as adjuvant treatment after incomplete Mohs micrographic surgery for large, mixed type basal cell carcinoma: a report of 3 cases. J Drugs Dermatol. 2006;5(5):461-464.

66. Gollnick H, Barona CG, Frank RGJ, et al. Eur J Dermatol. 2008;18(6):677-682.

67. Vidal D, Matias-Guiu X, Alomar A. Fifty five basal cell carciomas treated with topical imiquimod: outcome at 5-year follow-up. Arch Dermatol. 2007;143:266-268.

68. Drehs MM, Cook-Bolden F, Tanzi EL, Weinerg JM. Successful treatment of multiple superficial basal cell carcinomas with topical imiquimod: Case report and review of the literature. Dermatol Surg. 2002;28(5):427-429.

69. Chen TM, Rosen T, Orengo I. Treatment of a large superficial basal cell carcinoma with 5\% imiquimod: case report and review of the literature. Dermatol Surg. 2002;28:344-346.

70. Kagy MK, Amonette R. The use of imiquimod 5\% cream for the treatment of superficial basal cell carcinomas in a basal cell nevus syndrome patient. Dermatol Surg. 2000;26:577-578.

71. Micali G, Lacarrubba F, Nasca MR, De Pasquale R. The use of imiquimod $5 \%$ cream for the treatment of basal cell carcinoma as observed in Gorlins syndrome. Clin ExpDermatol. 2003;28(Suppl 1): 19-23. 
72. Brown VL, Atkins CL, Ghali L, Cerio R, Harwood CA, Proby CM. Safety and efficacy of $5 \%$ imiquimod cream for the treatment of skin dysplasia in high-risk renal transplant recipients: randomized, double-blind, placebo-controlled trial. Arch Dermatol. 2005;141(8): 985-993.

73. Wagstaff AJ, Perry CM. Topical imiquimod: a review of its use in the management of anogenital warts, actinic keratoses, basal cell carcinoma and other skin lesions. Drugs. 2007;67(15):2187-2210.
74. Kuijpers DI, Thissen MR, Berretty PJ, Ideler FH, Nelemans PJ, Neumann $\mathrm{MH}$. Surgical excision versus curettage plus cryosurgery in the treatment of basal cell carcinoma Dermatol Surg. 2007;33(5):579-587

75. Hall VL, Leppard BJ, McGill J, Kesseler ME, White JE, Goodwin P. Treatment of basal-cell carcinoma:comparison of radiotherapy and cryotherapy. Clin Radiol. 1986;37:33-34.

76. Lee S, Selva D, Huilgol S, Goldberg RA, Leibovitch I. Pharmacological treatments for basal cell carcinoma. Drugs. 2007;67(6):915-934.

\section{Publish your work in this journal}

Clinical, Cosmetic and Investigational Dermatology is an international, peer-reviewed, open access, online journal that focuses on the latest clinical and experimental research in all aspects of skin disease and cosmetic interventions. All areas of dermatology will be covered; contributions will be welcomed from all clinicians and basic science researchers globally. This journal is indexed on CAS. The manuscript management system is completely online and includes a very quick and fair peer-review system, which is all easy to use. Visit http://www.dovepress.com/testimonials.php to read real quotes from published authors.

Submit your manuscript here: http://www.dovepress.com/clinical-cosmetic-and-investigational-dermatology-journal 